\title{
Occurrence of Polyomaviruses in Recreational Freshwaters from Southern Brazil
}

\author{
Paulo Roberto Urbano*1, Viviane Girardi ${ }^{2}$, Cibele Odete Dantas Leal ${ }^{1}$, Vania Elisabete Schneider ${ }^{3}$, \\ Suelen Osmarina Paesi ${ }^{4}$, Fernando Rosado Spilki ${ }^{2}$ and Camila Malta Romano ${ }^{5}$ \\ ${ }^{1}$ Laboratório de Virologia, São Paulo, Brazil \\ ${ }^{2}$ Universidade Feevale, Brazil \\ ${ }^{3}$ Instituto de Saneamento Ambiental (ISAM), Brazil
}

${ }^{4}$ Instituto de Biotecnologia, Brazil

${ }^{5}$ Laboratório de Investigação Médica LIM52 do Hospital das Clinicas HCFMUSP, Brazil

*Corresponding author: Paulo Roberto Urbano, Laboratório de Virologia, São Paulo, Brazil

\begin{abstract}
ARTICLE INFO
Received: 幽 February 07, 2019

Published: 幽 February 19, 2019

Citation: Paulo Roberto U, Viviane G, Cibele Odete Dantas L, Vania Elisabete $\mathrm{S}$, Suelen Osmarina $\mathrm{P}$, et al. Occurrence of Polyomaviruses in Recreational Freshwaters from Southern Brazil. Biomed J Sci \& Tech Res 14(5)-2019. BJSTR. MS.ID.002603
\end{abstract}

Keywords: Freshwater; Polyomavirus; Environmental Spread; Jcpyv; Bkpyv; Mcpyv; Stlpyv; Tspyv
ABSTRACT

There is little information about the transmission pathways of polyomaviruses. Since many of them are regularly found in urine and feces, the possibility that the waterborne route could transmit these viruses has not been explored. The aim of this study was to evaluate the presence of human polyomaviruses JCPyV, BKPyV, MCPyV, STLPyV and TSPyV along the Belo River (Caxias do Sul-Rio Grande do Sul-RS, Brazil). Four points were investigated, with 13 monthly samplings (March/2015 - March/2016). A total of 52 samples were concentrated by ultracentrifugation, total genomic material was extracted using commercial extraction kit and human polyomaviruses were investigated through real time polymerase chain reaction. A total of 32/52 (61.5\%) positive samples were found. Only JCPyV and BKPyV were identified, and they were present in all sampling points. The average viral load of JCPyV was 7E+05 copies/mL and of BKPyV was 5E+04 copies/mL after particle concentration process. Finding such polyomaviruses in this environment suggests contamination through human waste and reinforce the notion that fecal-oral route may represent an important transmission mode for these viruses.

\section{Introduction}

The Polyomaviridae family consists of 100 viruses described so far, of which 13 can infect humans and 87 infect mainly fish, birds and other mammals [1-3]. Their genomes have relatively high similarity to each other and are homologous to SV40 polyomavirus [4]. Polyomaviruses have DNA genomes with approximately $5 \mathrm{k}$ bases that is divided into 3 regions named early, late and noncoding control region [1,2]. The first polyomavirus described was BK (BKPyV), which causes persistent subclinical infection in the kidneys of healthy individuals. In immunocompromised individuals, especially those undergoing renal transplantation, reactivation of BKPyV may cause clinical complications such as BKPyV- associated nephropathy and loss of the graft in the transplanted individual [5]. JC polyomavirus (JCPyV), discovered almost at the same time as BKPyV, is the etiologic agent of an extremely severe disease affecting also immunocompromised individuals, the progressive multifocal leukoencephalopathy (PML) [1,3]. MCPyV (Merkel-cell carcinoma polyomavirus), described in 2008 is the etiologic agent of an aggressive neuroendocrine carcinoma (Merkel Cell Carcinoma - MCC) that targets Merkel cells [6]. TSPyV was identified and sequenced from fragments of injured skin of an immunocompromised individual after cardiac transplantation with clinical evidence of a very rare skin cancer named Tricodisplasia spinulosa [7]. And, one of the most recent human polyomaviruses described is the Saint-Louis polyomavirus (STLPyV). It was detected in human feces by pyrosequencing8, but so far there is no association of STLPyV with diseases. 
The mode of transmission of polyomaviruses is still poorly understood, and multiple routes of infection including the contact with urine, feces, saliva and blood are likely [9-11]. Therefore, finding such viruses in water effluents may add a piece to the understanding the polyomaviruses transmission routes. Another concern regarding the presence of these viruses in waters regards to its oncogenic potential [12]. Waterborne diseases represent a serious public health problem in developing and undeveloped countries [13]. Secondary data from health reporting systems highlight viruses as as responsible for more than $7 \%$ of the cases of pathologies associated with water infection [14]. The frequency of these pathogens in water matrices and the negative effects on public health indicate the need to dispose of the wastewater before it is discharged into the environment [15]. Recreational water activities are common practice in countries with tropical climate as Brazil and contamination of water bodies can occur by polluting sources as domestic, agricultural and industrial effluents. In fact, recreational use is the main responsible for the onset of illnesses caused by contact with water, leading to disease outbreaks mainly during holidays and periods of warm weather [16,17].

In Brazil, the quality of water for recreational activities must comply with the standards established by CONAMA (Resolution 274 of November 29, 2000). According to this resolution, the fresh water bathing conditions are defined according to the counts of thermotolerant coliforms ( $E$ coli). However, it does not necessarily demonstrate the human origin of fecal material since E. coli is part of human and animal gut microbioma. Although there is no direct relation between coliforms and enteric viruses as indicators of fecal pollution, both parameters can be used as indicators of human waste contamination [18-21]. Some viruses are stable and often found in aquatic environments remaining potentially infectious for long time. Direct and prolonged exposure to enteric virus (i.e. Adenovirus, Rotavirus, Hepatitis A and Enterovirus) is the leading cause of gastroenteritis $[22,23,17]$. Nevertheless, it has been discussed that other viruses, not necessarily related to enteric diseases, would serve as markers for human waste contamination. As an example, the human specific polyomaviruses, which are frequent- ly shed in urine and feces, are very resistant to the environment, are worldwide prevalent and present no seasonality [24]. Some of them can even resist to environmental conditions and to water and sewage treatment since these processes are generally intended to bacterial control [25].

Belo River is one of the tributaries of the Caí River, located in the southwest of the city of Caxias do Sul and contributes to the formation of the Guaíba basin, responsible for the public supply of the capital Porto Alegre. This river has its sources in the urbanized and industrialized areas of Caxias do Sul, thus contributing with domestic and industrial effluents. During its journey, the river is also impacted with effluents from agricultural activities and livestock and close to these activities the waterway is used for leisure [26]. The aim of the present study was to evaluate the presence of human polyomaviruses in samples of the water source collected at distal points along the river flow.

\section{Materials and Methods}

The Belo River in Caxias do Sul, RS drains 21\% of the city's urban perimeter and has an area of $75.10 \mathrm{~km}^{2}$ and a perimeter of 63.11 $\mathrm{km}$ (479.000 inhabitants). Samplings were carried out monthly from March 2015 to March 2016 at four points along the Belo river, resulting in 52 samples $(50 \mathrm{~mL})$ collected from the surface. The local meteorological estimates were also evaluated. Description of the sampling points and respective GPS coordinates are described in Table 1. Concentration of viral particles was performed by the ultracentrifugation protocol described by Ruskowski [27]. Briefly, a $36 \mathrm{~mL}$ aliquot was separated from each sample and centrifuged at $41,000 \mathrm{Xg}$ at $80 \mathrm{C}$ for three hours. The pellet was re-suspended in $2 \mathrm{~mL}$ TE buffer (Tris-EDTA pH 8.0). To allow the material to be used in further studies, total genetic material (RNA and DNA) was extracted using the BioPur ${ }^{\circledR}$ kit from an initial volume of $200 \mu \mathrm{L}$ according to manufacturer instruction. cDNA was synthesized and template containing both DNA + cDNA was used for further experiments. TSPyV molecular detection was performed [28] using TaqMan method. Detection of JCPyV and BKPyV was performed according to Pal et al. [29] also using TaqMan methodology.

Table 1: Name, description and GPS coordinates of collection points along the Belo river.

\begin{tabular}{|c|c|c|c|}
\hline \multirow{2}{*}{ Collect Point } & \multirow{2}{*}{ Description } & \multicolumn{2}{|c|}{ GPS Coordinates } \\
\hline & & $\mathbf{X}$ & $\mathbf{Y}$ \\
\hline $\mathrm{P} 1$ & $\begin{array}{l}\text { Located within the urban area of Caxias do Sul, receives effluent of domestic origin, is upstream of the effluent } \\
\text { release from an animal processing industry. It consists of the point of evaluation of the quality of a stream } \\
\text { before the contribution of the industrial effluent. }\end{array}$ & 478024 & 6770622 \\
\hline $\mathrm{P} 2$ & $\begin{array}{l}\text { Located in the urban region, it is an established point for monitoring the quality of Belo river after its encoun- } \\
\text { ter with the industrial effluent. }\end{array}$ & 478845 & 6770010 \\
\hline P3 & $\begin{array}{l}\text { Located downstream of the confluence with the monitored stream (P1 and P2), in peri-urban area character- } \\
\text { ized by native vegetation and agricultural activities. This region receives domestic effluents. }\end{array}$ & 479051 & 6769817 \\
\hline $\mathrm{P} 4$ & $\begin{array}{l}\text { Located after a sewage treatment plant. It comprises the farthest point of the urbanized area upstream of the } \\
\text { Belo river basin, on the Caí river. It is characterized by areas of native vegetation and agricultural activities and } \\
\text { is used for recreation and aquatic recreation. }\end{array}$ & 482424 & 6757598 \\
\hline
\end{tabular}


The MCPyV primers were described by Goh et al. [30] and the primers used for STLPyV detection were designed based on reference sequence JX463183.1 using the online primer3 tool [31] (Forward - TACCATATTGTCCGCCCTAA; Reverse - TTGTGTCACTTGGGGAGAAT) generating a 179bp fragment. In house Real-time PCR (qPCR) protocols were developed for detection of both viruses: Real-time PCR mixes were prepared using $5 \mu \mathrm{L}$ of DNA, $12.5 \mu \mathrm{L}$ of SYBR $\AA$ Green PCR Master Mix (Applied Biosystems $®$ ), $0.5 \mu \mathrm{M}$ of each primer and $5.5 \mu \mathrm{l}$ of MilliQ water for final volume of $20 \mathrm{ul}$. The mixes were cycled 45 times at a Tm of $60 \mathrm{oC}$ in an ABI 7300 Real Time (Applied Systems $®$ ) and both reactions presented sensitivity of $1 \mathrm{E}+03$ copies/ $\mathrm{mL}$ (data not show). All samples were tested in duplicate. For statistical analysis the chi-square test was used with a significant level of 0.05 .

\section{Results}

A total of $32 / 52(61.5 \%)$ of samples tested positive for polyomavirus. From these, JCPyV represented 55,8\% (29/52), BKPyV was present in $26,9 \%$ (14 samples) and $21 \%$ of the samples was positive for both viruses. No other polyomaviruses investigated were identified. Regarding to the collect points, $30 \%$ of the positive samples were found in P1, 33,3\% in P2, 20\% in P3 and 23,3\% in samples collected in P4 (treated wastewater). The results classified by viruses and by collection points are shown in Table 2 . There was no significant difference on the distribution of positive samples according to collection points ( $\mathrm{p}=0.37$ ), nor according to seasonality $(p=0.3)$. Analyzing the viral load (VL) found in positive samples, JCPyV presented an average VL of 7E+05 copies/mL (5E+01 to $1.60 \mathrm{E}+03$ copies $/ \mathrm{mL}$ ), whereas positive samples for BKPyV presented a VL of $5 \mathrm{E}+04$ copies $/ \mathrm{mL}(8 \mathrm{E}+00$ to $1.8 \mathrm{E}+03$ copies $/ \mathrm{mL})$ after particle concentration process.

Table 2: Polyomavirus positivity according to the collect points.

\begin{tabular}{|c|c|c|c|c|}
\hline Collect Point Virus & P1 & P2 & P3 & P4 \\
\hline BKPyV & $14.2 \%$ & $28,6 \%$ & $28,6 \%$ & $28,6 \%$ \\
\hline JCPyV & $31 \%$ & $34,5 \%$ & $10,35 \%$ & $24,25 \%$ \\
\hline
\end{tabular}

The average annual temperature of the municipality is $16.3^{\circ} \mathrm{C}$. The warmest months are January and February, both averaging $20.6^{\circ} \mathrm{C}$, while June is the coldest, averaging $12.1^{\circ} \mathrm{C}$ (BDMEP Historical Series - Daily Data - Minimum Temperature $\left({ }^{\circ} \mathrm{C}\right)$ - Caxias do Sul - National Institute of Meteorology); the average of the annual rainfall index was $120 \mathrm{~mm}$ (BDMEP - Historical Series Daily Data - Precipitation (mm) - Caxias do Sul. National Institute of Meteorology). No seasonality was seen in the present data since the detection of the JCPyV and BKPyV DNA occurred in all months. The rainfall index and temperature variation during the seasons did not impact on the positivity found suggesting no variability between warmer (rainy) and colder months. For example, the highest rainfall index (199mm) was recorded in September and the lowest rainfall index $(118 \mathrm{~mm})$ was recorded in May. Both months presented 3 positive samples each.

\section{Discussion}

Samples collected in water resources with anthropogenic influence can harbor enormous microbiological diversity. In this work the presence of polyomaviruses JCPyV, BKPyV, MCPyV, STLPyV and TSPyV was evaluated and although polyomaviruses have already been found in human fluids1-5 including urine and feces, only JCPyV and BKPyV were found. BKPyV and JCPyV are globally distributed. Seroepidemiological data show that between 60 and 80 $\%$ of adults in the US and Europe carry these viruses, suggesting a common exposure route [32-35]. Despite the plenty of studies on distribution and excretion, the transmission routes of these viruses remain unknown. We detected JCPyV and BKPyV in all sampling points, ranging from 10 to $31 \%$ of positivity according to the local. These findings agree to the high prevalence of polyomavirus shedding in Brazil, ranging between $62 \%$ and $80 \%$ in immunocompetent and immunocompromised individuals respectively [36-38]. Besides the urine shed, it was already demonstrated that polyomaviruses are also found in feces of children and adults, with BKPyV being the most frequent in young children $[10,39]$.

Therefore, intense human activity due to the agricultural, urban and livestock runoffs at or near these collection points would explain such level of contamination since in addition to recreation, the river is used as a resource for survival and work [40]. Besides the present study, several groups have shown high prevalence of HPyVs in sewage and other water environments worldwide [41-43]. Polyomaviruses have also been described as being very resistance over time and is also resistant to treatments at low $\mathrm{pH}[41,44]$. This would explain why polyomaviruses are resistant to most sewage treatments protocols, in particular to chlorine treatment as JCPyV and BKPyV were also found in P4, after a sewage plant. Rivers located in the Mediterranean area in Barcelona (Spain) and Rio de Janeiro (Brazil), which receives domestic sewage from urbanized areas also were subject of analysis, revealing $100 \%$ positivity for JCPyV [45]. The presence of the JCPyV in water from the metropolitan area of Berlin was also demonstrated and agres to that JCPyV is the most prevalent polyomavirus in natural environments due to contamination with human wastes [46]. In agreement to our results, it was recently described the presence of JCPyV and BKPyV in water samples from a nearby region in Porto Alegre [47].

We did not observe MCPyV, TSPyV, and STLPyV at any sampling point. MCPyV virus was found in $50.3 \%$ of samples from urban sewage collected at wastewater treatment plants in several regions in Italy [43] and in 50\% in Barcelona (Spain) and Rio de Janeiro (Brazil) [45], suggesting that it may also be transmitted by fecal oral route. Although there is no report regarding to the MCPyV shedding in Brazil, approximately $20 \%$ of excretion was observed in the immunocompetent population (Urbano et al., unpublished data), which is much lower than the observed to BKPyV and JCPyV. Nevertheless, no positivity to MCPyV at all in our samples was an unexpected finding. It is possible that these viruses were present 
in the samples but at such low level that our methods were unable to detected them. To our knowledge, there is no data regarding to the rate of STLPyV in urine or TSPyV urine and fecal excretion in healthy individuals. Since these viruses also have high prevalence in general population [48-50], one may expect to find them at least in a proportion of the samples if these viruses would also use the fecal-oral route. In fact, it has been proposed that the respiratory tract may be the main route for TSPyV infection [51] and not the fecal-oral as it is suggested for JCPyV, BKPyV and MCPyV.

Freshwater is considered appropriate for use when it is in accordance with the bacterial levels accepted by CONAMA [52]. However, there is no treatment for viral removal in WWTP suggested by CONAMA and the presence of viruses can represent a public health problem [52-54]. As an example, RVA, NoV and HAdV were detected in the surface waters of the Rodrigo de Freitas Lagoon, which is considerate suitable for recreation according to the microbiological level's evaluation [53]. Some authors have suggested that the quality of river water (in terms of viruses presence) may be closely linked to the health status of the local population [54-56]. However, studies that also estimated viral load could not establish any relationship between viral load and probability of transmission $[53,56]$. In sum, as already seen in other regions, polyomaviruses are common in water matrices and we found them also in Belo River. Positive samples were detected during different months, regardless of season, temperature, rainfall, and direct or indirect human influence. Although no experiments were performed to evaluate the infectivity of viruses found in the Belo River, this data support the environmental spread and point to the need to further investigate the waterborne transmission of polyomaviruses.

\section{References}

1. Krumbholz A, Bininda Emonds OR, Wutzler P, Zell R (2009) Phylogenetics, evolution, and medical importance of polyomaviruses. Infect Genet Evol 9(5): 784-799.

2. Calvignac Spencer S, Feltkamp MCW, Daugherty MD, Moens U, Ramqvist T, et al. (2016) A taxonomy update for the family Polyomaviridae. Arch Virol 161(6): 1739-1750.

3. Moens U, Krumbholz A, Ehlers B, Zell R, Johne R, et al. (2017) Biology, evolution, and medical importance of polyomaviruses: An update. Infect Genet Evol 17(54): 18-38.

4. Khalili K (2001) Human neurotropic JC virus and its association with brain tumors. Dis Markers 17(3): 143-147.

5. Hirsch HH, Steiger J (2003) Polyomavirus BK. Lancet Infection Diseases 3(10): 611-623.

6. Viscidi RP, E Shah KV (2009) Cancer. A skin cancer virus? Science 319(5866): 1049- 1050.

7. Van Der Meijden E, Janssens RW, Lauber C, Bouwes Bavinck JN, Gorbalenya AE, et al. (2010) Discovery of a new human polyomavirus associated with trichodysplasia spinulosa in an immunocompromised patient. PLoS Pathog 6(7): 1001024.

8. Lim ES, Reyes A, Antonio M, Saha D, Ikumapayi UN, et al. (2013) Discovery of STL polyomavirus, a polyomavirus of ancestral recombinant origin that encodes a unique $\mathrm{T}$ antigen by alternative splicing. Virology 436(2): 295-303.
9. Randhawa PS, Rehman KK, Swalsky PA, Vats A, Scantlebury V, et al. (2002) DNA sequencing of viral capsid protein VP-1 region in patients with BK virus interstitial nephritis. Transplantation 73(7): 1090-1094.

10. Vanchiere JA, Abudayyeh S, Copeland CM, Lu LB, Graham DY, et al. (2009) Polyomavirus shedding in the stool of healthy adults. Journal of Clinical Microbiology 47(8): 2388-2391.

11. Bialasiewicz S, Byrom L, Fraser C, Clark J (2017) Potential Route of Transmission for Trichodysplasia Spinulosa Polyomavirus. J Infect Dis 215(7): 1175-1176.

12. Fratini M, Di Bonito P, La Rosa G (2014) Oncogenic Papillomavirus and Polyomavirus in Water Environments: Is There a Potential for Waterborne Transmission? Food Environ Virol 6(1): 1-12.

13. Heller L, Colosimo EA, Antunes CM (2003) Environmental sanitation conditions and health impact: a case-control study. Rev Soc Bras Med Trop 36(1): 41-50.

14. Benedict KM, Reses H, Vigar M (2017) Surveillance for Waterborne Disease Outbreaks Associated with Drinking Water -United States, 2013-2014. MMWR Morb Mortal Wkly Rep 66: 1216-1221.

15. Zhang, CM, Xu, LM, Xu PC, Wang XC (2016) Elimination of viruses from domestic wastewater: requirements and technologies. World J Microbiol Biotechnol 32(4): 1-9.

16. (2012) USEPA - United States Environmental Protection Agency. Guidelines for Water Reuse. Washington, USA.

17. Lodder WJ, Schijven JF, Rutjes SA, de Roda Husman AM, Teunis PF (2015) Entero and parechovirus distributions in surface water and probabilities of exposure to these viruses during water recreation. Water Res 75: 2532.

18. Pina S, Puig M, Lucena F, Jofre J, Girones R (1998) Viral pollution in the environment and in shellfish: human adenovirus detection by PCR as an index of human viruses. Appl Environ Microbiol 64(9): 3376-3382.

19. Wyn Jones AP, Carducci A, Cook N, D Agostino M, Divizia M, et al. (2011) Surveillance of adenoviruses and noroviruses in European recreational waters. Water Res 45(3): 1025-1038.

20. Dalla Vecchia A, Rigotto C, Staggemeier R, Soliman MC, Gil de Souza F, et al. (2015) Surface water quality in the Sinos River basin, in Southern Brazil: tracking microbiological contamination and correlation with physicochemical parameters. Environ Sci Pollut Res 22(13): 9899-9911.

21. Adefisoye MA, Nwodo UU, Green E, Okoh AI (2016) Quantitative PCR detection and characterization of human adenovirus, rotavirus and hepatitis A virus in discharged effluents of two wastewater treatment facilities in the Eastern Cape, South Africa. Food Environ. Virol 8(4): 262274.

22. Bosch A, Guix S, Sano D, Pintó RM (2008) New tools for the study and direct surveillance of viral pathogens in water. Curr Opin Biotechnol 19(3): 295-301.

23. Sinclair RG, Jones EL, Gerba CP (2009) Viruses in recreational waterborne disease outbreaks: a review. J Appl Microbiol 107(6): 1769-1780.

24. Rachmadi AT, Torrey JR, Kitajima M (2016) Human polyomavirus: Advantages and limitations as a human specific viral marker in aquatic environments. Water Res 105: 456-469.

25. (2006) Ministry of Health (2006) Secretariat of Health Surveillance. Surveillance and Control in Water Quality for Human Consumption.

26. Environmental Quality - Guaíba Hydrographic Region.

27. Ruskowski L (2015) Evaluation of ultracentrifugation and adsorptionelution methods for viral concentration in water samples. Monograph (Biomedicine course) - Feevale University, Novo Hamburgo-RS, Brazil.

28. Urbano PR, Nali LH, Bicalho CS, Pierrotti LC, David Neto E, et al. (2016) New findings about Trichodysplasia Spinulosa associated polyomavirus (TSPyV)-novel qPCR detects TSPyV-DNA in blood samples. Diagn Microbiol Infect Dis 84(2): 123-124. 
29. Pal A, Sirota L, Maudru T, Peden K, Lewis AM Jr (2006) Real-time, quantitative PCR assays for the detection of virus-specific DNA in samples with mixed populations of polyomaviruses. J Virol Methods 135(1): 32-42.

30. Goh S, Lindau C, Tiveljung Lindell A, Allander T (2009) Merkel Cell Polyomavirus in Respiratory Tract Secretions. Emerging Infectious Diseases 15(3): 489-491.

31. Rozen S, Skaletsky H (2000) Primer3 on the WWW for general users and for biologist programmers. Methods Mol Biol 132: 365-386.

32. Jin L, Pietropaolo V, Booth JC, Wark KH, Brown DW (1995) Prevalence and distribution of BK virus subtype in healthy people and immunocompromised patients detected by PCR-restriction enzymes analysis. Clinical and Diagnostic Virology 3(3): 285-295.

33. Milokanis E, Goes N, Rubin RH, Cosimi AB, Colvin RB, et al. (2001) BK virus in solid organ transplant recipients: an emerging syndrome. Transplantation 72(10): 1587-1592.

34. Egli A, Infanti L, Dumoulin A, Buser A, Samaridis J, et al. (2009) Prevalence of Polyomavirus BK and JC Infection and Replications in 400 Healthy Blood Donors. The Journal of Infectious Diseases 199(6): 837846.

35. Kean JM, Rao S, Wang M, Garcea RL (2009) Soroepidemiology of Human Polyomavirus. PLoS Pathogens 5(3): 1000363

36. Urbano PR, Nali LH, Bicalho CS, Pierrotti LC, David Neto E, et al. (2016) New findings about Trichodysplasia Spinulosa associated polyomavirus (TSPyV) -novel qPCR detects TSPyV-DNA in blood samples. Diagn Microbiol Infect Dis 84(2): 123-124.

37. Pires EP, Bernardino Vallinoto CV, Alves DM, Migone SR, Machado LF, et al. (2011) Prevalence of infection by JC and BK polyomaviruses in kidney transplant recipients and patients with chronic renal disease. Transpl Infect Dis 13(6): 633-637.

38. Nali LH, Centrone Cde C, Urbano PR, Penalva de Oliveira AC, et al. (2012) High prevalence of the simultaneous excretion of polyomaviruses JC and BK in the urine of HIV-infected patients without neurological symptoms in São Paulo, Brazil. Rev Inst Med Trop Sao Paulo 54(4): 201-205.

39. Vanchiere JA, Carillo B, Morrow AL, Jiang X, Ruiz Palacios GM, et al. (2016) Fecal Polyomavirus Excretion in Infancy. J Pediatric Infect Dis Soc 5(2): 210-213.

40. (2011) WHO Guidelines for drinking-water quality -( $3^{\text {rd }}$ edn). Geneva, Switzerland: WHO Press.

41. Bofill Mas S, Pina S, Girones R (2000) Documenting the epidemiologic patterns of polyomaviruses in human populations by studying their presence in urban sewage. Appl Environ Microbiol 66(1): 238-245.

42. Bofill Mas S, Formiga Cruz M, Clemente Casares P, Calafell F, Girones R (2001) Potential transmission of human polyomaviruses through the gastrointestinal tract after exposure to virions or viral DNA. J Virol 75(21): 10290-10299.

43. Di Bonito P, Libera SD, Petricca S, Iaconelli M, Accardi L, Muscillo M La Rosa G (2015) Frequent and abundant Merkel cell polyomavirus detection in urban wastewaters in Italy. Food Environ Virol 7(1): 1-6.

\section{ISSN: 2574-1241}

DOI: 10.26717.BJSTR.2019.14.002603

Paulo Roberto Urbano. Biomed J Sci \& Tech Res

This work is licensed under Creative Commons Attribution 4.0 License

Submission Link: https://biomedres.us/submit-manuscript.php
44. Bofill Mas S, Girones R (2003) Role of the environment in the transmission of JC virus. Journal of Neurovirology 9(1): 54-58.

45. Calgua B, Fumian T, Rusiñol M, Rodriguez Manzano J, Mbayed VA, et al (2013) Detection and quantification of classic and emerging viruses by skimmed-milk flocculation and PCR in river water from two geographical areas. Water Res 47(8): 2797-2810.

46. Hamza IA, Jurzik L, Stang A, Sure K, Uberla K, Wilhelm M (2009) Detection of human viruses in rivers of a densly-populated area in Germany using a virus adsorption elution method optimized for PCR analyses. Water Res 43(10): 2657-2668.

47. Comerlato J, Souza Campos F, Souza Arantes T, Roos Kulmann MI, Trindade Oliveira M, et al. (2017) Distribution and genetic diversity of the human polyomaviruses JC and BK in surface water and sewage treatment plant during 2009 in Porto Alegre, Southern Brazil. Braz J Biol 77(3): 459-468.

48. Nicol JT, Robinot R, Carpentier A, Carandina G, Mazzoni E, et al. (2013) Age-specific seroprevalences of merkel cell polyomavirus, human polyomaviruses 6, 7, and 9, and Trichodysplasia Spinulosa associated polyomavirus. Clin Vaccine Immunol 20(3): 363-368.

49. Fukumoto H, Li TC, Kataoka M, Hasegawa H, Wakita T, et al. (2015) Seroprevalence of Trichodysplasia Spinulosa associated polyomavirus in Japan. J ClinVirol 65: 76-82.

50. Šroller V, Hamšíková E, Ludvíková V, Musil J, Němečková Š, et al. (2016) Seroprevalence rates of HPyV6, HPyV7, TSPyV, HPyV9, MWPyV and KIPyV polyomaviruses among the healthy blood donors. J Med Virol 88(7): 1254-1261.

51. Van Der Meijden E, Horváth B, Nijland M, de Vries K, Rácz EK, et al. (2017) Primary Polyomavirus Infection, Not Reactivation, as the Cause of Trichodysplasia Spinulosa in Immunocompromised Patients. J Infect Dis 215(7): 1080-1084.

52. CONAMA Resolution (2201) "Revises the criteria for Balneability in Brazilian Waters" - Date of legislation: 29/11/2000 - DOU Publication, pp. 70-71.

53. Vieira CB, Mendes AC, Guimarães FR, Fumian TM, Leite JP, et al. (2012) Detection of enteric viruses in recreational waters of an urban lagoon in the city of Rio de Janeiro, Brazil. Mem Inst Oswaldo Cruz 107(6): 778784 .

54. Carducci A, Morici P, Pizzi F, Battistini R, Rovini E, Verani M (2008) Study of the viral removal efficiency in a urban wastewater treatment plant. Water Sci Technol 58(4): 893-897.

55. Espinosa AC, Arias CF, Sánchez Colón S, Mazari Hiriart M (2009) Comparative study of enteric viruses, coliphages and indicator bacteria for evaluating water quality in a tropical high-altitude system. Environ Health 8: 49.

56. Prevost B, Lucas FS, Goncalves A, Richard F, Moulin L, et al. (2015) Large scale survey of enteric viruses in river and waste water underlines the health status of the local population. Environ Int. 79: 42-50.

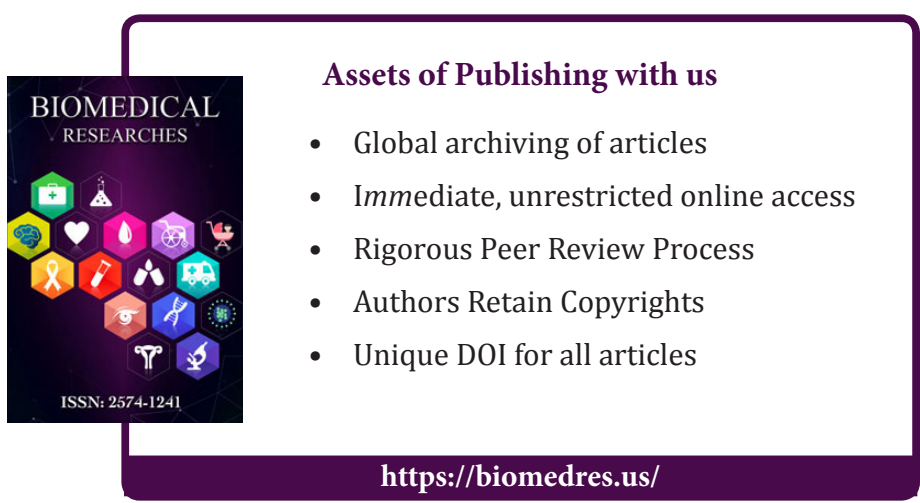

